УДК 343.102

DOI https://doi.org/10.32849/2663-5313/2020.4.62

Анатолій Яровий,

аспірант відділу аспірантури

Міжрегіональної академії управління персоналом

\title{
КЛАСИФІКАЦІЯ УПОВНОВАЖЕНИХ СУБ'ЄКТІВ (ІНІЦАТОРІВ) ПРОВЕДЕННЯ НЕГЛАСНИХ СЛІДЧИХ (РОЗШУКОВИХ) ДІЙ ТА ЗДІЙСНЕННЯ КОНТРОЛЬНО-НАГЛЯДОВИХ ФУНКЦЙ ЗА ДОТРИМАННЯМ ПРАВ І СВОБОД ЛЮДИНИ
}

\begin{abstract}
У роботі розкрито поняттєво-категорійний зміст термінологічної конструкиії «суб'єкти проведення негласних слідчих (розшукових) дій (далі - НСРД) та здійснення контрольно-наглядових функиій». Автор, дослідивши сучасний стан розроблення означеної в темі наукової прачі проблеми, заявляє, що питання системного підходу до розуміння поняттєво-категорійного змісту термінологічної конструкиії «суб'єкти проведення НСРД та здійснення контрольно-наллядових функиій» у контексті «проиесуального й організачійного забезпечення порядку проведення НСРД» так і не знайшло не лише комплексного наукового осмислення, а й навіть однозначного розв'язання в науиі й практииі кримінального прочесу.

Аналізуючи наукові позиії багатьох учених, автор висновує, що суб'єкти проведення НСРД та здійснення контрольно-наглядових функиій як окремий інститут є складовою ширшого за полярністю поняття «суб'єкти кримінального провадження» у співвідношенні частини (суб'єкти проведення НСРД та здійснення контрольно-наглядових функиій) до иілого (суб'єкти кримінального провадження). Автором представлена термінологічна конструкція «суб'єкти проведення НСРД та здійснення контрольно-наглядових функиій», яка структурно має дві складові, як-от «суб'єкти проведення НСРД» $i$ «суб'єкти здійснення контрольно-наглядових функиій над проведенням НСРД».

Висловлюється авторська позииія, що суб'єктів проведення (ініиіаторів) НСРД $і$ здійснення контрольно-наглядових функиій слід класифікувати за виконуваною роллю, процесуальним статусом і функиіональною діяльністю, розподіливши на п'ять груп. Отже, до «суб'єктів (інічіаторів) проведення НСРД» віднесено таких осіб: слідчого (детектива НАБУ), прокурора (прочесуального керівника), керівника органу досудового розслідування, керівника слідчого підрозділу, співробітників оперативних підрозділів відповідних правоохоронних відомств, спеиіаліста, конфідента або, як висловлюються в кримінально-прочесуальній науиі та практииі, «іншу особу». До «суб'єктів здійснення контрольно-наглядових функиій над проведенням НСРД» слід віднести слідчого (детектива НАБУ), керівника органу досудового розслідування, керівників уповноважених оперативних підрозділів, прокурора - процесуального керівника (керівників прокуратур різних рівнів), слідчого суддю та суд.
\end{abstract}

Ключові слова: реалізація повноважень, прокурор, слідчий, детектив, співробітник оперативного підрозділу, НСРД, кримінальне провадження, судовий контроль, слідчий суддя.

Постановка проблеми. Для з'ясування заявленого в назві представленої наукової праці проблеми насамперед необхідно уточнити сутність і зміст категорії «суб'єкт» у загальнофілософському розумінні й теорії права. Відомо, що будь-яка термінологія має свій іманентний поняттєвий апарат, тобто систему понять, що відображають сутність предмета, різновид зв'язку його структурних елементів, процеси його генезису, функціонування й розвитку $[1$, c. 7]. На думку деяких учених, така система понять дає цілісний погляд на суспільне явище й визначення його сутності [2, с. 47].

У контексті означеного слід звернутися до семантико-праксичного, герменев- тичного аналізу поняття «суб'єкт», що, 3 визнаної позиції авторського колективу «Великого тлумачного словника сучасної української мови», представлений як істота, що здатна до пізнання навколишнього світу, об'єктивної дійсності й до цілеспрямованої діяльності; особа (група осіб), організація тощо, яким належить активна роль у певному процесі, акті; особа чи організація як носії певних прав та обов'язків; людина як носій певних фізичних і психічних якостей тощо [3, с. 1408-1409]. Наведене розуміння терміну «суб'єкт» цілком відповідає уяві загальної теорії права про суб'єктів, до яких належать фізичні та юридичні особи, 
територіальні громади, держави, які є носіями встановлених законом прав й обов'язків [4, с. $312 ; 5$, с. $146 ; 6$, с. 67].

Дослідження поняттєво-категорійного, етимологічного змісту термінологічної конструкції «суб'єкти проведення НСРД і здійснення контрольно-наглядових функцій», що вбудовані в розуміння «процесуального й організаційного забезпечення порядку проведення НСРД», почасти відображено в роботах багатьох вітчизняних учених, зокрема Л. Лобойка, В. Назарова, В. Нора, Д. Письменного, Н. Сизої, А. Туманянц, Л. Удалової, О. Шило та інших. Натомість питання системного підходу до розуміння поняттєво-категорійного змісту термінологічної конструкції «суб'єкти проведення НСРД і здійснення контрольно-наглядових функцій» i їх класифікації так і не знайшли однозначного вирішення в науці кримінального процесу.

Метою статті $є$ дослідження сучасного стану наукового обгрунтування категорійно-поняттєвого змісту термінологічної конструкції «суб'єкти проведення НСРД i здійснення контрольно-наглядових функцій», розроблення авторської класифікації суб'єктів проведення НСРД і здійснення контрольно-наглядових функцій і пропозиція її використання в теорії кримінально-процесуальної науки.

Виклад основного матеріалу. Розкриваючи сутність поняття «суб'єкт» 3 юридичної точки зору, варто звернути увагу на той факт, що в науково-правових колах у цьому контексті оперують двома термінами: «суб'єкт права» й «суб'єкт правовідносин», які, на перший погляд, хоча і є схожими категоріями, водночас мають специфічні відмінності в конкретному випадку. Для прикладу, «суб'єкт права» може й не бути учасником правовідносин, однак має потенційну можливість вступати в останні, наділяючись відповідною правосуб'єктністю [7, с. 111]. На думку О. Скакун, суб'єкти правовідносин використовують свою правосуб'єктність у конкретних правовідносинах, оскільки стають реалізаторами суб'єктивних прав і юридичних обов'язків, повноважень, а також юридичної відповідальності [8, с. 519]. Саме цей підхід нами використовується для подальшого висвітлення питання щодо розуміння суб'єктів (ініціаторів) проведення НСРД і здійснення контрольно-наглядових функцій» у кримінальному процесі України.

Слід зауважити, що в кримінальному процесуальному законодавстві України відсутнє визначення поняття термінологічної конструкції «суб'єкти проведення
НСРД і здійснення контрольно-наглядових функцій», однак вживаються інші терміни: «учасники кримінального провадження», «учасники судового провадження», «сторони кримінального провадження». Поглиблений аналіз чинного Кримінального процесуального кодексу України від 2012 р. (далі - КПК України), як відзначив О. Кіпер, дає можливість стверджувати, що найширшим є поняття «суб'єктів кримінального провадження», до яких належать узагалі всі суб'єкти кримінально-процесуальних відносин, а саме: державні органи й посадові особи, які ведуть кримінальне провадження; особи, які залучаються до кримінального провадження для захисту своїх прав й законних інтересів або для виконання своїх обов'язків; особи, які сприяють здійсненню кримінального провадження тощо [9, с. 13]. Вони, констатує автор, здійснюють кримінально-процесуальну діяльність, виступають носіями прав й обов'язків і беруть активну участь у кримінально-процесуальній діяльності, а тому можуть бути названі суб'єктами кримінального процесу (провадження) [9, с. 12].

Як принагідно зазначає В. Пожар, немає й не може бути суб'єкта кримінально-процесуального права, що існує незалежно від участі в провадженні в конкретній справі. Поза цією участю, поза процесом, на думку автора, неможливо мати й здійснювати (виконувати) процесуальні права й обов' язки [10, с. 468]. Означене співвідноситься зі сталою думкою О. Скакун, згідно з якою лише суб'єкт права може бути суб'єктом правовідносин [8, с. 519]. Також варто погодитися з думкою О. Харитонової про те, що суб'єкт правовідносин володіє конкретним правом і перебуває в правовому зв'язку з іншим учасником (учасниками) суспільних відносин, на яких нормами законодавства покладаються обов'язки, що відповідають праву уповноваженої особи [11, с. 101].

Спираючись на наукову позицію О. Кіпера щодо розуміння широти полярності поняття «суб'єктів кримінального провадження» [9, с. 13], вважаємо, що «суб'єкти проведення НСРД та здійснення контрольно-наглядових функцій» є його складовою у співвідношенні частини (суб'єкти проведення НСРД $i$ здійснення контрольно-наглядових функиій) до цілого (суб'єкти кримінального провадження). Представлена нами в назві наукової праці термінологічна конструкція «суб'єкти проведення негласних слідчих (розшукових) дій i здійснення контрольно-наглядових функцій» структурно має дві складові, як-от: «суб'єкти проведення НСРД» і «суб'єкти здійснення контрольно-наглядових функцій над проведенням НСРД». 
Як слушно зазначив С. Тагієв, суб'єкти проведення НСРД являють собою неуніфіковану інституцію, оскільки складаються 3 численних учасників кримінального провадження [12, с. 161]. На цьому ж акцентує й В. Колесник, зважаючи на більш широке коло суб'єктів, що можуть залучатися до проведення НСРД, а саме працівників оперативних чи оперативно-технічних підрозділів правоохоронних органів, спеціалістів, перекладачів, окремих громадян, осіб, які співпрацюють з оперативними підрозділами на конфіденційній основі тощо [13, с. 132].

3'ясувавши сутність і зміст поняття «суб’єкти проведення НСРД і здійснення контрольно-наглядових функцій», можливо перейти до вирішення наукового завдання наукової праці: їх («суб'єктів проведення НСРД і здійснення контрольно-наглядових функцій») класифікації. Як цілком слушно зауважує Д. Приймаченко, «в результаті класифікації відбувається приріст знань про досліджуваний об'єкт або накопичені знання створюють певну систему, що дозволяе більш чітко відобразити його особливості» [14, с. 258]. У філософії поняття «класифікація» використовується для позначення засобу або процесу розбиття множини (класу) об'єктів на підмножини (підкласи) за певними ознаками. Класифікація (типологія) може бути здійснена за різними ознаками (підставами), тобто так званими критеріями класифікації, під якими в науково-правових колах розуміють певні риси й особливості того чи іншого суб'єкта, на підставі яких можливе його об'єднання в певні класифікаційні групи, визначення як спільних, так і відмінних ознак кожної з них [15, с. 275].

Тож, відповідно до запропонованої нами в назві представленої роботи термінологічної конструкції «суб'єкти (ініціатори) проведення НСРД і здійснення контрольно-наглядових функцій» до «суб'єктів (ініціаторів) проведення НСРД» слід віднести таких осіб: слідчого (детектива НАБУ), керівника органу досудового розслідування, співробітників оперативних підрозділів відповідних правоохоронних відомств, спеціаліста, конфідента чи, як висловлюються в кримінально-процесуальній науці та практиці, «іншу особу».

Однак попри спільність віднесення як слідчого (детектива НАБУ), прокурора процесуального керівника, керівника органу досудового розслідування, співробітників оперативних підрозділів правоохоронних органів, спеціалістів і конфідентів (інших осіб) до суб'єктів проведення НСРД між ними існує певна функціональна відмінність, а саме: слідчий (детектив НАБУ), керівник органу досудового розслідування є одночасно ініціаторами (організаторами) й уповноваженими на безпосереднє проведення НСРД; прокурор - процесуальний керівник уповноважений лише ініціювати (доручати) проведення НСРД; співробітники оперативних підрозділів є лише виконавцями (реалізаторами) НСРД, натомість спеціалісти, залучені конфіденти та «інші особи» виступають винятково реалізаторами НСРД, що виконують лише забезпечувальну функцію для оптимізації здійснення повноважень слідчого (детектива НАБУ) та співробітників оперативних підрозділів правоохоронних органів.

Водночас до «суб'єктів здійснення контрольно-наглядових функцій над проведенням НСРД» слід віднести таких осіб: слідчого (детектива НАБУ), керівника органу досудового розслідування, керівників уповноважених оперативних підрозділів, прокурора - процесуального керівника, керівників прокуратур різних рівнів; слідчого суддю й суд. До речі, контроль за проведенням НСРД у теорії кримінального процесуального права класифікують за різними ознаками. Так, залежно від етапу проведення НСРД можна виокремити такі види контролю: попереджувальний, поточний і подальший. Своєю чергою за обсягом перевірки розрізняють такі види контролю: загальний, спеціальний і відомчий (галузевий) [16]. Щодо відомчого контролю, то, як наголошують М. Денисенко та Я. Стрелюк, він повинен охоплювати всі сторони діяльності оперативних підрозділів, усі аспекти застосування ними спеціальних сил, засобів і методів, а також усіх осіб, які реалізують НСРД. І, як зауважують учені, «результативність такого контролю залежить від ефективності організації його проведення» $[17$, c. 134].

Для того щоб детальніше розібратися 3 повноваженнями означених суб'єктів у здійсненні контрольно-наглядових функцій над проведенням НСРД, необхідно герменевтично (етимологічно) розмежувати поняттєво-категорійний інструментарій структурних складових представленої термінологічної конструкції. На нашу думку, абсолютно логічним буде спершу проаналізувати такі категорії як «досудовий контроль», «судовий контроль» і «нагляд» у межах єдиної консолідованої поняттєво-термінологічної конструкції «контрольно-наглядові функції». Ці терміни є доволі схожими між собою й свідчать про те, що контроль - це взаємовідносини між тим, хто перевіряє й наділений владними повноваженнями, і тим, кого перевіряють [18, с. 166-168]. Деякі автори ототожнюють поняття контролю 
й нагляду. Для прикладу, М. Студенкіна вважає, що нагляд є різновидом контролю, оскільки охоплює різні сфери управління не обмежуючись колом питань, пов'язаних 3 дотриманням законодавчих норм. Водночас нагляд це спостереження за точним виконанням чинних у різних сферах норм [19, с. 18]. Детальніше на означених суб'єктах здійснення контрольно-наглядових функцій над проведенням НСРД ми зупинимося в наступній науковій праці, присвяченій саме цій проблемі.

\section{Висновки}

Означене вище уможливило представлення класифікації суб'єктів (ініціаторів) проведення негласних слідчих (розшукових) дій та здійснення контрольно-наглядових функцій за виконуваною роллю, процесуальним статусом, функціональною діяльністю учасників НСРД і розподілення їх за визначеними критеріями на такі групи:

1) суб'єкти, які виконують контрольнонаглядові функції в проведенні НСРД (слідчий (детектив НАБУ), керівник органу досудового розслідування, керівники уповноважених оперативних підрозділів, прокурор - процесуальний керівник (керівники прокуратур різних рівнів); слідчий суддя та суд);

2) суб'єкти, які безпосередньо проводять НСРД (слідчий (детектив), співробітники (уповноважені керівники) оперативних підрозділів відповідних відомств правоохоронних органів);

3) суб'єкти, що ініціюють проведення НСРД (слідчий (детектив), прокурор - процесуальний керівник, керівник органу досудового розслідування);

4) суб'єкти, що залучені до реалізації НСРД (спеціаліст, конфідент і «інша особа», залучена до реалізації НСРД);

5) суб'єкти, що не проводили, не реалізовували, не залучалися й не контролювали здійснення НСРД, але можуть бути ознайомлені зїх (НСРД) матеріалами в разі відкриття матеріалів досудового розслідування (кримінального провадження) іншій стороні згідно зі ст. 290 КПК України (адвокати, потерпілі, представник юридичної особи, законні представники, підозрювані, свідки, представники потерпілого та інші), оскільки невідкриття в порядку, визначеному ст. 290 КПК України, дає всі підстави судам вважати докази, здобуті з порушенням вимог КПК України, неналежними (ст. 86 КПК України) [20].

Вважається, що з метою законодавчого унормування діяльності суб'єктів (ініціаторів) 3 проведення та контролю реалізації НСРД доцільно внести доповнення до ч. 1 ст. 3 КПК України (назва - «Визначення основних термінів кодексу»), доповнивши іï пунктом «27» і викласти його в такій авторській редакції:

27) Суб'єкти (ініціатори) проведення негласних слідчих (розшукових) дій та здійснення контрольно-наглядових функцій: суб'єкти (ініціатори) проведення негласних слідчих (розшукових) дій: слідчий (детектив НАБУ), прокурор (прочесуальний керівник), керівник органу досудового розслідування, співробітники оперативних підрозділів відповідних правоохоронних відомств, спеціаліст, конфідент та «інша особа», яка залучена для реалізащї НСРД. Суб'єкти здійснення контрольно-наглядових функиій над проведенням НСРД: слідчий (детектив НАБУ), керівник органу досудового розслідування, керівник слідчого підрозділу, керівники уповноважених оперативних підрозділів, прокурор (керівники прокуратур різних рівнів); слідчий суддя ma суд.

\section{Список використаних джерел:}

1. Витрук Н.В. Основы теории правового положения личности в социалистическом обществе. Москва : Наука, 1979. 229 с.

2. Арсеньев А.С., Библер Б.С., Кедров Б.М. Анализ развивающегося понятия. Москва : Наука, 1967. 439 с.

3. Великий тлумачний словник сучасної української мови / Уклад. і голов. ред. В.Т. Бусел. Київ, Ірпінь : Перун, 2009. 1736 с.

4. Зайчук О.В., Оніщенко Н.М. Теорія держави і права. Академічний курс : підручник / За ред. О.В. Зайчука, Н.М. Оніщенко. Київ : Юрінком Інтер, 2006. 685 c.

5. Протасов В.Н. Теория права и государства. Проблемы теории права и государства. Вопросы и ответы. Москва : Новый Юрист, 1999. 240 с.

6. Алексеев С.С. Общая теория права : в 2 т. Т. 2. Москва : Юридическая литература, 1982. $360 \mathrm{c}$

7. Миськів Л.І. Адміністративно-правові засади діяльності вищих навчальних закладів МВС України з питань морально-правового виховання курсантів : дис. ... канд. юрид. наук : 12.00.06. Харків, 2008. 203 с.

8. Скакун О.Ф. Теорія держави і права (енциклопедичний курс) : Підручник. Вид. 2-ге. Харків : Еспада, 2009. 752 c

9. Кіпер О.О. Процесуальна самостійність слідчого як гарантія всебічного, повного й неупередженого розслідування у кримінальному провадженні : дис. ... канд. юрид. наук : 12.00.09. Одеса, 2017. 228 c.

10. Пожар В.Г. Щодо термінологічного визначення категорії «суб'єкти кримінального провадження» та його співвідношення 3 суміжними поняттями. Правове життя сучасної України : матер. міжнар. наук. конф. проф. викл. складу, 
16-17 травня 2013 р. Т. 2. / Відп. за вип. д. ю. н. проф. В.М. Дрьомін ; Націон. ун-т «Одеська юридична академія». Одеса : Фенікс, 2013. С. 467-468.

11. Фінансове право : підручник / М.П. Кучерявенко та ін. ; за ред. д-ра юрид. наук, проф. М.П. Кучерявенка. Харків : Право, 2013. 400 с.

12. Тагієв С.Р. Негласні слідчі (розшукові) дії у кримінальному судочинстві України: монографія. Київ : Дакор, 2015. 440 с.

13. Колесник В.А. Суб'єкти здійснення та класифікація негласних слідчих (розшукових) дій. Юридичний часопис Начіональної академії внутрішніх справ. 2013. № 1. С. 129-134.

14. Приймаченко Д.В. Адміністративна діяльність митних органів у сфері реалізації митної політики держави : дис. ... док. юрид. наук : 12.00.07. Дніпропетровськ, 2007. 468 с

15. Музичук О.М. Контроль за діяльністю правоохоронних органів в Україні : монографія. Харків: ХНУВС, 2010. 654 с
16. Кислий А.М. Актуальні питання організації відомчого контролю за оперативно-розшуковою діяльністю. Боротьба з організованою злочинністю і корупиією (теорія і практика). 2012. № 1 (29). С. 212-216.

17. Денисенко М., Стрелюк Я. Окремі аспекти організації контролю за проведенням негласних слідчих (розшукових) дій. Национальный юридический журнал: теория и практика. 2015. № 2. T. 1. C. $130-135$.

18. Рохлин В.И. Прокурорский надзор и государственный контроль : история, развитие, понятие, соотношение. Санкт-Петербург : Юрид. центр Пресс, 2003. 305 с

19. Студенкина М.С. Государственный контроль в сфере управления. Проблемь надведомственного контроля. Москва : Юрид. лит., 1974.160 с.

20. Кримінальний процесуальний кодекс України : Закон України від 13 квітня 2012 р. № 4651-VI. Голос України. 2012. № 90-91.

The paper covers conceptual and categorical content of the terminological structure "subjects of covert investigative (search) activities and implementing control and oversight functions". Having examined the current situation in the development of the problem identified in the topic of the paper, the author states that in the science and practice of the criminal process there is neither a comprehensive scientific understanding of, nor even an unambiguous solution of the issue of a systematic approach to understanding the conceptual and categorical content of the terminological structure "subjects of covert investigative (search) activities and implementing control and oversight functions" in the context of "procedural and organizational support of conducting covert investigative (search) activities". Having analyzed the scientific positions of a number of scientists, the author concludes that the subjects of covert investigative (search) activities and implementing control and oversight functions as a separate institution constitute an element of a wider polarity concept of "subjects of criminal proceedings" in the balance between a part (subjects of covert investigative (search) activities and implementing control and oversight functions) and the whole (subjects of criminal proceedings). The author suggests that the terminological structure "subjects of covert investigative (search) activities and implementing control and oversight functions" structurally has two components, i.e., "subjects of covert investigative (search) activities" and "subjects implementing control and oversight functions over the CISA".

The author's position is that the subjects (initiators) of covert investigative (search) activities and implementing control and oversight functions should be classified according to their role, standing and functional activity that are divided into five groups. Therefore, "subjects (initiators) of covert investigative (search) activities" include: investigator (NABU detective), officer of the pre-trial investigation body, officer of the investigative unit, the operative units of the relevant law enforcement agencies, a specialist, a confidant or "another person", a phrase used in criminal procedural science and practice. The "subjects implementing control and oversight functions over CISA" shall include: investigator (NABU detective), officer of the pretrial investigation body, officers of authorized operative units, officer of the investigative unit, prosecutor supervisor of pre-trial proceedings, heads of prosecutor of fices at various levels; investigating judge and court.

Key words: exercise of powers, prosecutor, investigator, search, officer of operative unit, CISA, criminal proceedings, judicial control, investigating judge. 